\title{
A Floral Ontogenetic Approach to Questions of Homology within the Cyperoideae (Cyperaceae)
}

\author{
A. Vrijdaghs ${ }^{1,5}$ - A. M. Muasya ${ }^{2}$ - P. Goetghebeur ${ }^{3}$. \\ P. Caris ${ }^{1} \cdot$ A. Nagels ${ }^{1} \cdot$ E. Smets ${ }^{1,4}$ \\ ${ }^{1}$ Laboratory of Plant Systematics, Institute of Botany and Microbiology, K.U. Leuven, Kasteelpark \\ Arenberg 31, 3001 Leuven, Belgium \\ ${ }^{2}$ Botany Department, University of Cape Town, Rondebosch 7701, South Africa \\ ${ }^{3}$ Research Group Spermatophytes, Department of Biology, Ghent University, K.L. Ledeganckstraat 35, \\ 9000 Gent, Belgium \\ ${ }^{4}$ National Herbarium of The Netherlands, Leiden University Branch, P.O. Box 9514, 2300 RA Leiden, \\ The Netherlands \\ ${ }^{5}$ Author for Correspondence; e-mail: alexander.vrijdaghs@bio.kuleuven.be \\ Published online: 5 December 2008 \\ (C) The New York Botanical Garden 2008
}

\begin{abstract}
Within the Cyperoideae, which comprise all Cyperaceae except the Mapanioideae, several questions of homology are discussed and reinterpreted based on results of our SEM and LM floral ontogenetic studies. In all species studied, spikelets are interpreted as being indeterminate, with spirally to distichously arranged glumes, each subtending (or not) a flower. Floral development starts with the formation of two lateral stamen primordia, simultaneously with, or followed by the formation of a third, abaxial stamen primordium. Perianth parts, if present, originate only after the formation of the androecium, simultaneously with the appearance of an annular ovary primordium, surrounding a central ovule primordium. Perianth parts vary in number and morphology, and, where present, perianth development follows a general pattern. Three (or two) stigma primordia are formed on the top of the rising ovary wall. In dimerous gynoecia, stigma primordia originate either dorsiventrally, resulting in a laterally flattened ovary/nutlet, or laterally, resulting in a dorsiventrally flattened ovary/nutlet. We conclude that in all species studied the spikelet and floral development occurs according to a general, scirpoid, ontogenetic pattern, which we illustrate using new spikelet and floral ontogenetic results in Eleocharis palustris and other species. Spikelet and floral ontogeny in species with apparently deviating morphologies, can be traced back to the general ontogenetic pattern.
\end{abstract}

Resumen Varias preguntas sobre homología para las Cyperoideae, que incluyen todas las Cyperaceae excepto las Mapanioideae, se discuten e interpretan con base en estudios de ontogenia floral realizados con SEM y LM. En todas las especies estudiadas, las espiguillas son indeterminadas con glumas arregladas en espiral o dicotomicamente, cada una sosteniendo (o no) una flor. El desarrollo floral comienza con la formación de dos primordios estaminales laterales, simultáneamente con o seguido por la formación del tercer primordio estaminal abaxial. Si se desarrollan las partes del perianto, se originan solo después de la formación del androceo, 
simultáneamente con el desarrollo del primordio anular del ovario que envuelve al primordio central del óvulo. Cuando están presentes las partes del perianto, varían en número y morfología y el desarrollo sigue un patrón general. Se forman tres (o dos) primordios del estigma en el ápice de la pared del ovario en desarrollo. En gineceos dímeros, los primordios de los estigmas se originan dorsiventralmente resultando en una nuececilla/ovario comprimido lateralmente, o se originan lateralmente, resultando en una nuececilla/ovario comprimido dorsiventralmente. Concluimos que, tanto el desarrollo floral, como el de las espiguillas en todas las especies estudiadas, siguen un patrón ontogenético general scirpoide que se ilustra con los resultados obtenidos para Eleocharis palustris y otros especies. La ontogenia floral y de las espiguillas en especies con morfologías aparentemente atípicas, puede estar reducida al patrón ontogenetico general.

Keywords Cyperaceae $\cdot$ Cyperoideae $\cdot$ Floral Ontogeny $\cdot$ Homology $\cdot$ SEM

\section{Introduction}

Based on recent molecular phylogenetic analyses, Simpson et al. (2007) and Muasya et al. (this volume A) proposed maintenance of only two subfamilies within Cyperaceae, Mapanioideae and Cyperoideae. Cyperoideae comprise all genera of Cyperaceae previously classified in subfamilies Cyperoideae (including Hellmuthia Steudel), Caricoideae and Sclerioideae except the former Mapanioideae sensu Goetghebeur (1998). Within Cyperoideae four major clades include: (1) a Schoeneae clade (with Schoenus L. and Cladium P. Browne), (2) a Scirpeae clade, including species of the former Cariceae, Dulichieae, and Scirpeae (sensu Goetghebeur, 1998), (3) a clade including Abildgaardieae (e.g. Fimbristylis Vahl), sister to Fuireneae (e.g. Fuirena Rottb. and Schoenoplectus (Reichb.) Palla), and Eleocharideae (e.g. Eleocharis R.Br.), and (4) Cypereae (Muasya et al., this volume B). Consequently, in this paper, the terms "Cyperoideae" and "cyperoid" refer to the non-mapanioid Cyperaceae, including Hellmuthia (Muasya et al., 2000; Simpson et al., 2007; Muasya et al., this volume A). However, since the (molecular) phylogenetic hypotheses on (supra)generic level have not yet been stabilized, we use, unless otherwise stated, tribes and genera as proposed by Goetghebeur (1998).

The aim of this paper is to present a survey of our on-going research on floral and spikelet ontogeny in Cyperoideae, proposing a general floral ontogenetic model for Cyperoideae illustrated with new SEM data. In an earlier publication, we illustrated the general floral ontogenetic model for Cyperoideae with SEM images of the floral ontogeny in Scirpus sylvaticus L. (Vrijdaghs et al., 2005a). Here, we applied it to flowers in Eleocharis palustris (L.) Roem. \& Schult., and to flowers of several other species with modified flowers (Table 1). In contrast to flowers in S. sylvaticus, flowers in E. palustris have a reduced number of perianth parts and a dimerous gynoecium.

In our project, we focused on species within the above mentioned four clades (Muasya et al., this volume A; Table 2). Our selection was based on the availability of material suitable for studies aiming to find floral and spikelet ontogenetic answers for the many homology questions within Cyperaceae. There have been long-standing discussions about the monopodial or sympodial construction of the spikelet. Some 
Table 1 Genera Investigated for Our On-going Research Subdivided into Groups Following Four Main Clades of Cyperoideae According to Simpson et al. (2007)

\begin{tabular}{|c|c|c|c|}
\hline Group 1 & Group 2 & Group 3 & Group 4 \\
\hline${ }^{\mathrm{a}}$ Carex L. & ${ }^{\mathrm{a}}$ Fimbristylis Vahl & ${ }^{\mathrm{a}}$ Cyperus L. & Cladium P. Browne \\
\hline${ }^{\mathrm{a}}$ Kobresia Willd. & ${ }^{\mathrm{a}}$ Bulbostylis & ${ }^{\mathrm{a} C o u r t o i s i n a}$ Sojàk & Lepidosperma Labill. \\
\hline 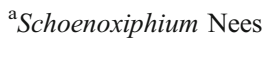 & Kunth & ${ }^{\mathrm{a}}$ Queenslandiella Domin & $\begin{array}{l}\text { a Machaerina Vahl (former } \\
\text { Baumea Gaudich.) }\end{array}$ \\
\hline Uncinia Pers. & & $\begin{array}{l}{ }^{\mathrm{a}} \text { Lipocharpha } \mathrm{R} . \mathrm{Br} . \\
\text { Hellmuthia } \text { Steudel } \\
\text { a Kyllingiella } \mathrm{R} . \\
{ }^{\mathrm{a}} \text { Kyllinga } \text { Rottb. } \\
{ }^{\mathrm{a}} \text { Pycreus } \text { P. Beauv. }\end{array}$ & $\begin{array}{l}\text { Schoenus L. } \\
{ }^{\mathrm{a} C o s t u l a r i a ~ C . B . ~ C l a r k e}\end{array}$ \\
\hline${ }^{\mathrm{a}}$ Blysmus Panzer ex & Eleocharis R.Br. & Ficinia Schrad. & \\
\hline Schultes & & Isolepis R.Br. & \\
\hline Dulichium Rich. & & $\begin{array}{l}\text { Scirpoides Scheuchzer } \\
\text { ex Séguier }\end{array}$ & \\
\hline \multicolumn{4}{|l|}{$\begin{array}{l}\text { Eriophorum L. } \\
\text { Scirpus L. }\end{array}$} \\
\hline & $\begin{array}{l}\text { Fuirena Rottb. } \\
{ }^{\text {a Schoenoplectus }} \\
\text { (Reichb.) Palla }\end{array}$ & & \\
\hline
\end{tabular}

${ }^{\mathrm{a}}$ Unpublished results

Table 2 Survey of Floral Ontogenetic Research Since Payer (1857)

\begin{tabular}{ll}
\hline Payer (1857) & Carex schreberi Willd., Eriophorum polystachion L., \\
Scirpus (=Eleocharis) palustris L.
\end{tabular}
Scirpus (=Eleocharis) palustris L.

Schumann (1890)

Barnard (1957)

Schultze-Motel (1959)

Mora (1960)

Mora (1960)

Mora-Osejo (1987)

Bruhl (1991)

Richards (2002)

Vrijdaghs et al. (2003a)

Vrijdaghs et al. (2003b)

Vrijdaghs et al. (2004)

Zhang et al. (2004)

Vrijdaghs et al. (2005a)

Vrijdaghs et al. (2005b)

Richards et al. (2006)

Vrijdaghs et al. (2006)
Carex gracilis Kurt., C. hirta L., C. riparia L., C. spartea

Spr., Scirpus (=Bolboschoenus) maritimus L.,

Schoenoxiphium lanceum K. Sch., S. rufum Nees

Cyperus eragrostis Lam., Scirpus (=Schoenoplectus) validus Vahl, Cyperus congestus Vahl., C. eragrostis

species in Carex L., Cladium P. Browne, Cyperus L., Eleocharis R.Br., Oreobolus R. Br. Scirpus L.,

Schoenus L., Uncinia Pers.,

Uncinia hamata (Sw.) Urb.

Dulichium arundinaceum (L.) Britton, Eriophorum angustifolium Roth., Scirpus (=Scirpoides) holoschoenus L., Scirpus (=Schoenoplectus) lacustris L.

Schoenoplectus (Reichb.) Palla, Eleocharis L.

Cladium jamaicense Crantz.

Schoenus nigricans L.

Cladium mariscus (L.) Pohl

Fuirena abnormalis C.B. Clarke, F. ciliaris (L.) Roxb., F. leptostachya Oliver, F. pubescens (Poir.) Kunth spikelet morphology in Schoeneae

Dulichium arundinaceum (L.) Britton, Eriophorum latifolium Hoppe, Scirpoides holoschoenus (L.) Sojàk, Scirpus sylvaticus L. Cyperus haspan L., Ficinia brevifolia Nees ex Kunth, F. capitella (Thunb.) Nees, F. gracilis Schrad., F. minutiflora C.B. Clarke, F. radiata (L.f.) Kunth, F. zeyheri Boeck, Isolepis antarctica (L.) Roem. \& Schult., I. setacea (L.) R.Br. Exocarya sclerioides (F. Muell.)

Hellmuthia membranacea (Thunb.) Haines \& Lye Paramapania parvibractea (Clarke) 
authors, beginning with Pax (1886) and Celakovsky (1887), considered the zigzag spikelets in Rhynchosporeae to be rhipidium-like. A rhipidium is a (cymously) built partial inflorescence in which the prophyll of a lateral axis subtends a new lateral axis, each axis ending in a flower. In Cyperaceae, such pattern would result in a zigzag pseudorachilla. Similar controversy has been going on about the nature of the flower (e.g. Bruhl, 1991), the nature of the perianth parts in genera such as Dulichium L. C. Rich. (e.g. Mattfeld, 1938), Eriophorum L. (e.g. Mora-Osejo, 1987) or Fuirena (e.g. Kern, 1962), or the nature of particular structures like for example the gynophore in Ficinia Schrad. Most of these discussions followed from different opinions about spikelet and floral structure, according to whether the author supported a euanthial (e.g. Eiten, 1976; Goetghebeur, 1998; Haines \& Lye 1976) or a pseudanthial (e.g. Holttum, 1948; Mattfeld, 1938; Schultze-Motel, 1959; Kern, 1962) interpretation. With our spikelet and floral ontogenetic observations, we aimed to contribute to resolve these homology questions. For example, in Hellmuthia, the presence of two lateral, keeled scales in the proximal flowers of the spikelet caused this genus to be classified in the Mapanioideae (Haines and Lye 1976). However, recent phylogenetic analyses based on combined molecular and palynological data (Muasya et al., 1998, 2000; Simpson et al., 2007) placed Hellmuthia in a clade with former Cypereae. Ontogenetic observations showed that the lateral floral scales in Hellmuthia are not homologous with the scales in mapanioid Cyperaceae (Vrijdaghs et al., 2006). Following Dahlgren et al. (1985) and Kubitzki (1987), we consider cyperoid flowers to be derived from a typical trimerous, actinomorphic, diplostemonous, monocot flower with a superior syncarpous pistil (e.g. Rudall and Bateman, 2003), because in flowers in Juncaceae this pattern is common. In the consensus tree of Plunkett et al. (1995), Cyperaceae, Juncaceae and Prionium form a clade with Prionium basal and sister to the other taxa. Prionium (now included in Thurniaceae; APG 2003) has a typical juncaceous flower, which allowed to infer that Juncaceae are more similar to the common ancestor than the Cyperaceae (Simpson 1995). In most Cyperoideae, however, only one haplostemonous whorl of stamens remains. Consequently, a typical cyperoid flower is tetracyclic with two alternating whorls of three perianth members, one whorl of three stamens opposite the outer perianth parts, and a trimerous gynoecium (e.g. Vrijdaghs et al., 2005a).

Until now, floral and spikelet ontogenetic studies on Cyperaceae have been sporadic (Table 3). The first SEM observations date from the early nineties, when Bruhl (1991) presented a SEM developmental study in species of Schoenoplectus (Reichb.) Palla, and Eleocharis. Since then, SEM has become an important tool for floral ontogenetic studies. Richards et al. (2006) published recently a remarkable floral ontogeny in Exocarya (Mapanioideae, Chrysitricheae).

\section{Material and Methods}

Partial inflorescences of the species studied were collected in the field or in botanical gardens (Table 1) and fixed in FAA (70\% ethanol, acetic acid, 40\% formaldehyde, 90:5:5). Floral buds were dissected in 70\% ethanol under a Wild M3 stereo microscope (Leica Microsystems AG, Wetzlar, Germany) equipped with a cold-light source (Schott KL1500; Schott-Fostec LLC, Auburn, New York, USA). 
Table 3 Species of Cyperoideae Studied and Voucher Data

\begin{tabular}{|c|c|c|c|}
\hline Species & Origin & Date & Voucher number \\
\hline Cyperus friburgensis Boeckeler & CULT., UGent & 2002 & P. Goetghebeur 5869 \\
\hline Dulichium arundinaceum (L.) Britton & CULT., UGent & 2003 & P. Goetghebeur 9914 \\
\hline Eleocharis palustric & $\begin{array}{l}\text { CULT., Municipal Bot. } \\
\text { Garden Leuven }\end{array}$ & 09/Apr/02 & A. Vrijdaghs 07 \\
\hline Fuirena ciliaris (L.) Roxb. & Northern Territory, Australia & & R.K. Harwood 1173 \\
\hline Fimbristylis ferruginea & Kenya & & A.M. Muasya 2127 \\
\hline $\begin{array}{l}\text { Hellmuthia membranacea } \\
\text { (Thunb.) Haines \& Lye }\end{array}$ & Cape of Good Hope & 31/Jul/05 & B. Byetebier 2645 \\
\hline $\begin{array}{l}\text { Hellmuthia membranacea } \\
\text { (Thunb.) Haines \& Lye }\end{array}$ & Cape of Good Hope & $\mathrm{Jul} / 2005$ & A.M. Muasya 2792 \\
\hline Lepidosperma tetraquetum Nees & Western Australia & $\begin{array}{c}03 / \text { Oct/ } \\
2003\end{array}$ & J. Hodgon 737 \\
\hline Pycreus pumilus Nees & Kenya & & A.M. Muasya 2157 \\
\hline Scirpoides holoschoenus (L.) Sojàk & $\begin{array}{l}\text { CULT. Municipal } \\
\text { Bot. Garden Leuven }\end{array}$ & & A. Vrijdaghs 03 \\
\hline Scirpus sylvaticus L. & CULT. K.U. Leuven & & A. Vrijdaghs 02 \\
\hline Uncinia rubra Colenso ex Boott & CULT., UGent & Oct/2001 & P. Goetghebeur 9727 \\
\hline
\end{tabular}

The material was washed twice with $70 \%$ ethanol for $5 \mathrm{~min}$ and then placed in a mixture (1:1) of 70\% ethanol and DMM (dimethoxymethane) for $5 \mathrm{~min}$. Subsequently, the material was transferred to $100 \%$ DMM for $20 \mathrm{~min}$, before it was critical point dried using liquid $\mathrm{CO}_{2}$ with a CPD 030 critical point dryer (BALTEC AG, Balzers, Liechtenstein). The dried samples were mounted on aluminium stubs using Leit-C and coated with gold with a SPI-Module ${ }^{\mathrm{TM}}$ Sputter Coater (SPI Supplies, West-Chester, PA, USA). Images were obtained with a Jeol JSM-6360 (JEOL Ltd., Tokyo) at the Laboratory of Plant Systematics (K.U. Leuven), and with a JEOL JSM-5800 LV scanning electron microscope at the National Botanic Garden of Belgium in Meise.

For light microscopic observations, developing spikelets of Hellmuthia membranacea (Thunb.) Haines \& Lye were dehydrated through a $t$-butyl alcohol series to be embedded in paraffin. Transverse and longitudinal serial sections (Microm HM360) were cut at $12 \mu \mathrm{m}$ thickness and stained with safranin in $70 \%$ ethanol and aniline blue in an automatic Varistain staining machine 24-3 (Shandon, Rundcorn, United Kingdom) and mounted with Eukitt. LM images were observed with a Leitz Dialux 20 microscope (Germany) and digital photographs made with a Olympus DP50 camera (Germany).

\section{Results}

Floral Ontogeny in Eleocharis palustris

The spikelet in Eleocharis palustris consists of an indeterminate rachilla (Fig. 1a) and many spirally placed glumes subtending (or not) a flower (Fig. 1a,b). A floral primordium (Fig. 1c) expands laterally, forming two lateral stamen primordia (Fig. 1d). Simultaneously, a third, abaxial stamen primordium becomes apparent 

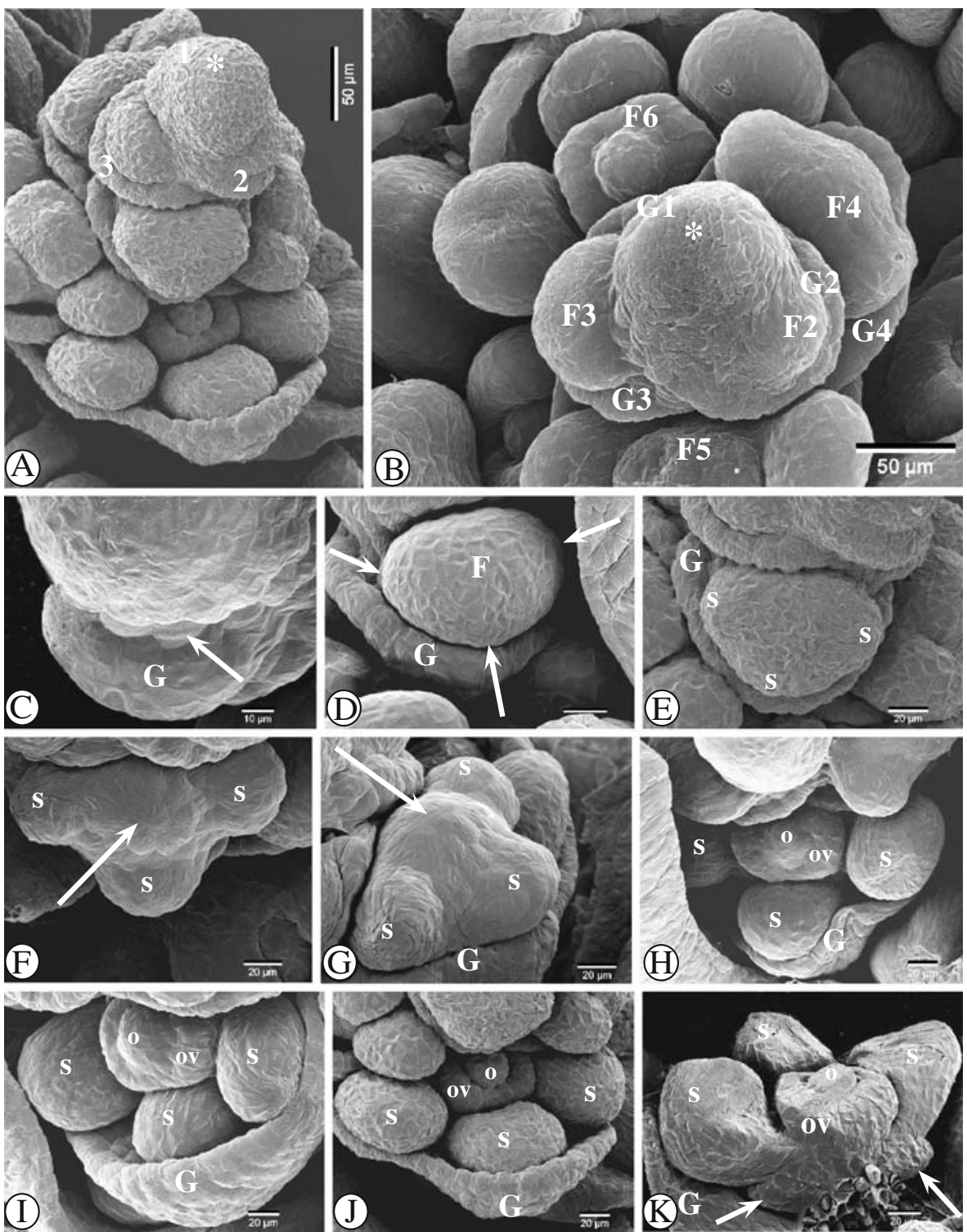

Fig. 1 Floral ontogeny in Eleocharis palustris. a Distal part of a spikelet with rachilla apex and successive stages of early floral development (numbered 1-3). b Apical view of the spikelet apex with spirally placed glumes $(G 1-4)$ and different stages of floral development $(F 1-6)$. c Newly formed glume with axillary floral primordium (arrowed). d Floral primordium, forming two lateral and one abaxial stamen primordia (arrowed). e Apical view of a floral primordium with two lateral and one abaxial stamen primordia. $\mathbf{f}$ Apical view of a floral primordium with swelling floral apex (arrowed). $\mathbf{g}$ Lateral view of a floral primordium with swelling floral apex (arrowed). h-j Apical-abaxial view. An annular primordium surrounding a central ovule primordium originates on the floral apex. k Adaxial view with two outer perianth primordia (arrowed). Captions Fig. 1. * Spikelet apex. $F$ flower (primordium). $G$ (flower subtending) glume (primordium). o ovule primordium. ov ovary wall (primordium). $s$ stamen (primordium) 
(Fig. 1d,e). Next, the floral apex swells (Fig. 1f,g) and forms two primordia, an annular ovary primordium surrounding a central ovule primordium (Fig. 1h-k). At this stage, the filaments and anthers have differentiated, and the bristle primordia appear (Fig. 1k) outside the stamens. There are three outer perianth primordia opposite the stamens, and only one inner bristle primordium at the adaxial side of the gynoecium (Fig. 2a-e). Meanwhile, the ovary wall grows up and on the top of it two lateral stigma primordia appear (Fig. 2a,b). The ovary wall envelops the central ovule primordium, and the stigma primordia grow out into two stigmas (Fig. 2b-d). Meanwhile, an apiculus is formed on the top of each anther (Figs. 2c-g, $3 \mathrm{~g}$ ) and the base of each microsporangium becomes papillose (Fig. 3h). The bristle primordia elongate (Fig. $2 \mathrm{~b}-\mathrm{g}$ ). They become typical bristles with retrorse barbs. The bristles tend to grow along the slids of the anthers (Fig. 2h). Meanwhile, a short stylar zone has been formed (Fig. 2i), which subsequently lengthens and swells at its base, forming an bipartite inversed heart-shaped (cordate) structure (Fig. 3a-d). The surface of the thickened style base becomes covered with unicellular trichomes (Fig. 3d,i). At the same time the stigma primordia grow out into two long papillose, laterally oriented, stigmatic branches, which protrude above the glume before the stamens stretch (Fig. 3f). At anthesis, the filaments as well as the anthers of the stamens elongate considerably, lifting the anthers beyond the protection of the subtending glume and exposing them to the wind (Fig. 3f). Eventually, the style withers, though the thickened style base is persistent. The bristles also remain attached to the fruit and fall with it (Fig. 3e).

\section{Additional Observations}

The distal parts of the spikelets of Scirpus sylvaticus, Fuirena ciliaris, Dulichium arundinaceum, Fimbristylis ferruginea, Scirpoides holoschoenus, Cyperus friburgensis, Pycreus pumilus, and of the spike and female spikelet of Uncinia rubra have an indeterminate axis apex (Fig. 4a-i).

In spikelets of Hellmuthia membranacea, lateral axes occur in glume-like bracts on the proximal part of the spikelet (Fig. 5a).

In some spikelets of Pycreus pumilus, there is variation in number of stamens per flower in the same spikelet. Flowers with zero, one, or two stamens can be found (Fig. 5b).

In the distal part of a spikelet in Lepidosperma tetraquetrum, the flowers are dislocated with respect to their subtending glumes (Fig. 5e). The rachilla apex together with the distal glume (G1) is situated in between the lifted flower primordium (F2), and the developing flower (F3). In F3, three out of four stamen primordia are visible, as well as the outer perianth parts. In this species, the flowers are tetramerous. An annular ovary primordium is formed, surrounding a central ovule primordium. At this stage, four stigma primordia are already appearing.

Male flowers in Uncinia rubra are spirally placed on the distal part of the spike axis, each subtended by a glume-like bract (Fig. 6a,c). The floral primordium forms three staminal primordia (Fig. 6a). Each stamen primordium develops into a filament and anther (Fig. 6b,c). Female flowers originate in a one-flower spikelet subtended by a bract (Fig. 6d-f). The flower is subtended by the spikelet prophyll, which forms an utriculus that envelops flower, rachilla and distal glume (Fig. 6d-f). The flower 

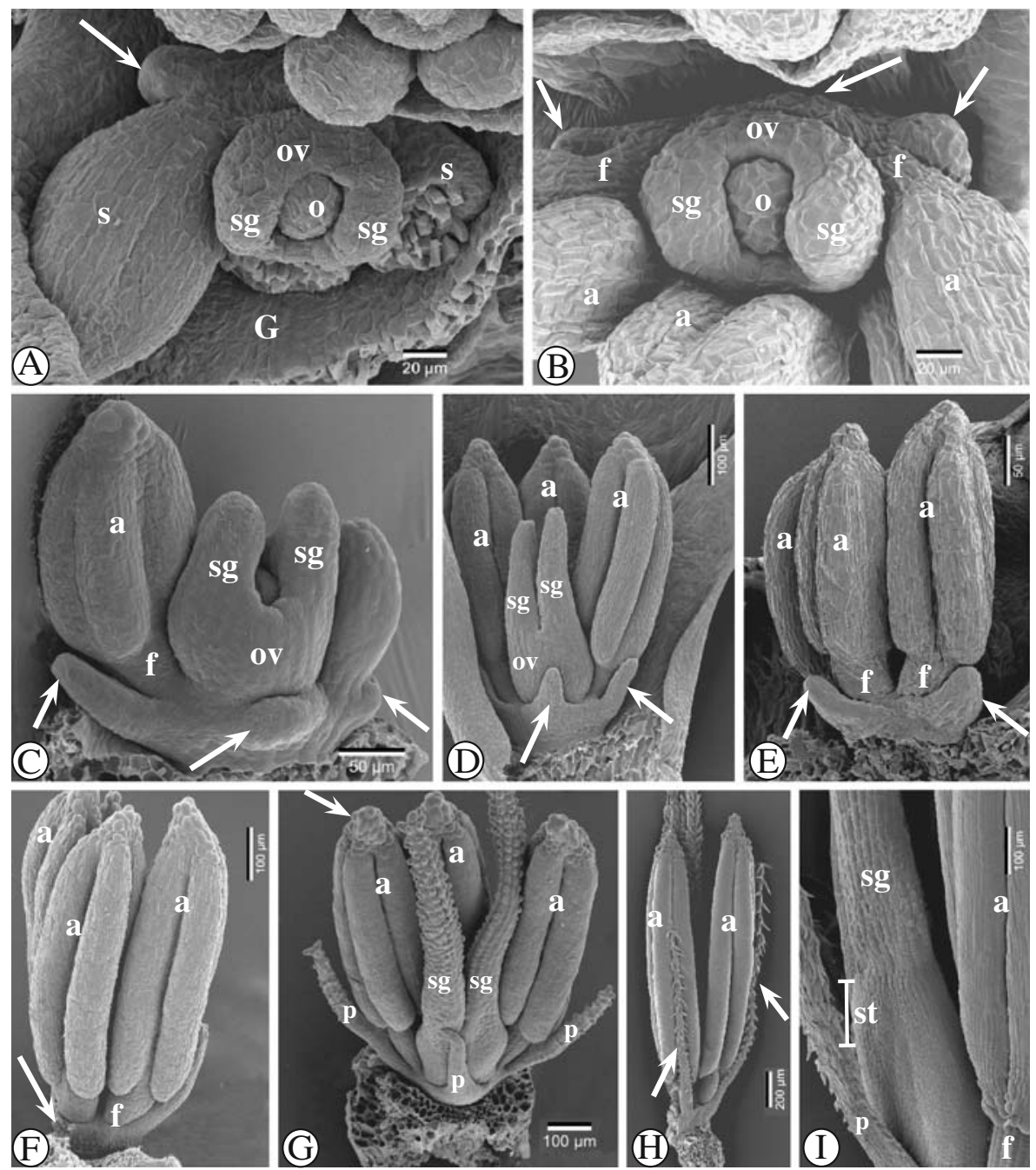

Fig. 2 Floral ontogeny in Eleocharis palustris. a Apical view of a developing flower. Two lateral stigma primordia appear on the top of the developing ovary wall. One bristle primordium is visible (arrowed). The anther at right hand side has been removed. b Apical view of a developing flower. Two lateral outer and one adaxial, inner perianth part primordia are visible (arrowed). The stamens start developing into filament and anther. $\mathbf{c}-\mathbf{d}$. Adaxial view of two successive developmental stages. The stigmas are growing up. Filament and anther are formed, and the perianth parts (arrowed) elongate. e Lateral-abaxial view of a flower, with developing perianth parts (arrowed). f Lateral abaxial view. The abaxial bristle has been removed (arrowed). On the top of each stamen, a connective crest is formed. $g$ Adaxial view of a semimature flower. The stigmas become papillose. Barbs are being formed on the bristles. The apiculus on the top of each stamen becomes an elaborate, papillose structure (arrowed). $\mathbf{h}$ The retrorse bristles (arrowed) elongate along the slides of the anthers. i A single style appears (barred). Captions for Fig. 2. $a$ anther. $f$ filament. $G$ (flower subtending) glume (primordium). $o$ ovule primordium. ov ovary wall (primordium). $p$ perianth part. $s$ stamen (primordium). $s g$ stigma (primordium). st style 

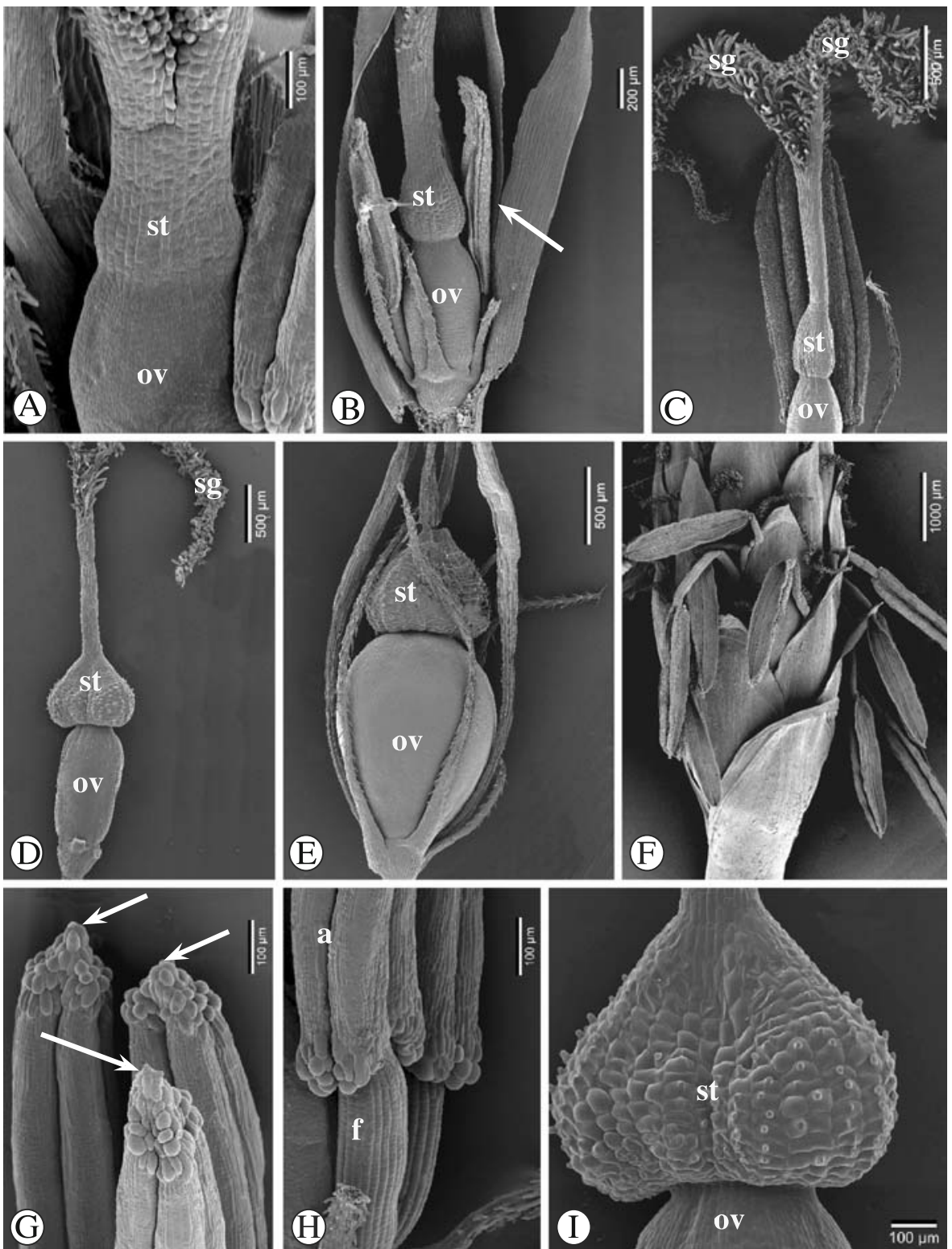

Fig. 3 The floral ontogeny in Eleocharis palustris. a Gynoecium with developing style. The style basis is already distinct from the rest of the style. b Adaxial view of a nearly mature flower with thickening style basis. The subtending glume is very broad, with lateral wings tending to tear off at later stages (arrowed). c Elongating style with thickening style base, and mature, papillose stigmas. d Near anthesis, a thickened style base with papillose surface is formed. e After anthesis, the style withers. The thickened style base, however, is persistent, as well as the bristles and some anther filaments. f Proximal part of a mature spikelet, with only stigmas protruding beyond the subtending glumes in the upper part, and emptied anthers and old stigmas in the lower part. $\mathbf{g}$ Detail of apiculi (arrowed) on the tops of the anthers. h Nearly mature stamens with base of each microsporangium (arrowed) papillose. i Detail of the thickened style base with papillose surface. $a$ anther. $f$ filament. $G$ (flower subtending) glume (primordium). $o v$ ovary wall (primordium). $s g$ stigma (primordium). st style 

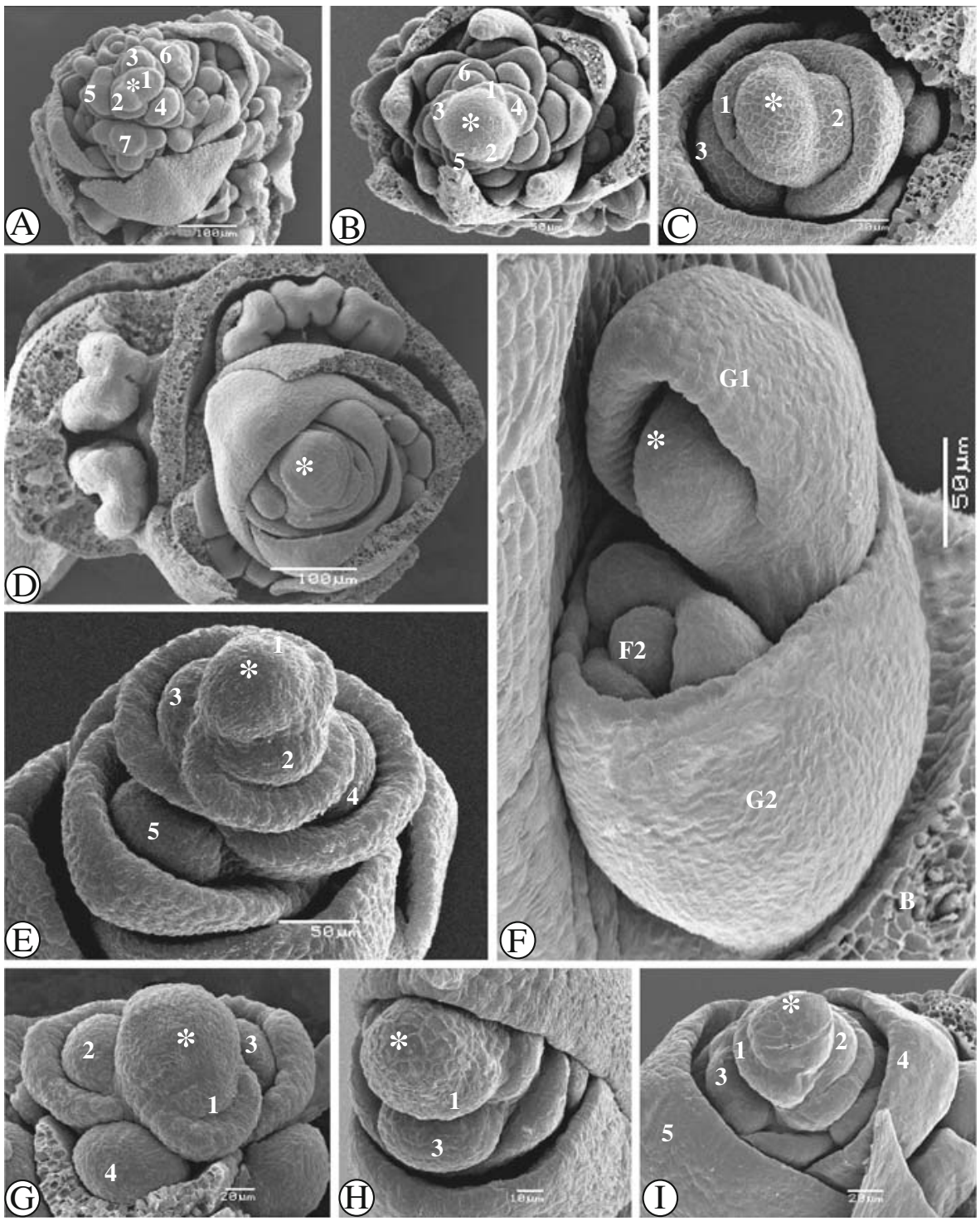

Fig. 4 Spikelet apices in species of representative genera in Cyperoideae. Apical view of spikelet apices in: a Scirpus sylvaticus. $1=$ youngest glume; $2-7$ are floral primordia at successive developmental stages. b Fuirena ciliaris. 1 and 2=originating glumes. 3-6 are floral primordia at successive developmental stages. c Dulichium arundinaceum. $1=$ originating glume. 2 and 3 are floral primordia at successive developmental stages. d Fimbristylis ferruginea. e Uncinia rubra. $1=$ originating glume-like bract. 2 and 3 are (male) floral primordia at successive developmental stages. $4=$ developing glume(-like) bract. f Uncinia rubra. The "hook" in the rachilla is formed by the distal glume (1). The proximal glume (G2), which is a modified prophyll or utriculus, subtends the developing female flower $(F 2$, three stigma primordia, surrounding a central ovule primordium). $\mathbf{g}$ Lateral-apical view of the distal part of a spikelet in Scirpoides holoschoenus. $1=$ originating glume. 1-4 are floral primordia at successive developmental stages. h Lateral-apical view of the distal part of a spikelet in Cyperus friburgensis. $1=$ originating glume. 2 is not visible. 3 is a very early floral primordium. $\mathbf{i}$ Lateral view of the distal part of a spikelet in Pycreus sanguinolentus. $1=$ originating glume. 2 and 3 are floral primordia at successive developmental stages. 4 and $5=$ developing flower subtending glume. Captions for Fig. 4 . * top of the axis. $B$ subtending bract of spikelet. $F$ flower (primordium). $G$ (flower subtending) glume (primordium) 
primordium develops into a pistillate flower, forming an ovary wall with three stigma primordia (Fig. 6e,f).

\section{Discussion}

Cyperoid flowers are typical trimerous monocot flowers. However, flowers in Lepidosperma tetraquetum differ from the typical trimerous pattern, having a tetragonal culm and tetramerous flowers (Fig. 5e). Also in other angiosperm species, a tetragonal culm goes often together with a tetramerous organisation of the flower (Goetghebeur, unpublished results). In our future research, we hope to clarify the many modifications in inflorescence, spikelet and floral structure by comparing floral ontogenetic patterns in Lepidosperma and other Schoeneae with the general floral ontogenetic model for Cyperoideae.

The use of spikelet and floral ontogenetic data constrains us to apply a strictly morphological homology concept, free of any phylogenetic interpretation. Moreover, our conclusions have been limited to assessment of 1:1 correspondences (Sattler, 1984 , 1994) between structures or ontogenetic patterns. Consequently, we have applied Remane (1952) "position criterion" to all ontogenetic stages (e.g. the whorl where a structure or its primordium is positioned), as well as his "criterion of special quality" (the presence or absence of a typical property used to define a particular structure, e.g. the vascularisation of floral parts). Our conclusions (putative homologies) were compared with molecular phylogenetic data; synapomorphies (homologies obtained as a result of cladistic analysis, e.g. Patterson 1982; Nelson 1994; Lauder 1994) and, where significant, a phylogenetic interpretation were added (Fig. 7). For example, the presence of glume-like bracts subtending a rudimentary lateral axis in the proximal part of the spikelet in Hellmuthia allowed us to homologize a spikelet in Hellmuthia with a partial inflorescence (Vrijdaghs et al., 2006), purely on morphological-ontogenetic grounds. On the other hand, molecular phylogenetic studies revealed a basal position of Hellmuthia within Cypereae (e.g. Muasya et al., 1998). Consequently, we hypothesised that spikelets in Cypereae are derived from partial inflorescences by reduction (Vrijdaghs et al., 2006).

\section{Inflorescence and Spikelet}

A cyperoid inflorescence has been described either as (1) a compound multiple spike because of the indeterminate nature of the ultimate inflorescence units (Kukkonen, 1994), or (2) paniculate (Raynal, 1971), in which the individual flowers of the panicle sensu Troll (1959) are replaced by spikelets. Since the spikelets are open, the inflorescence is polytelic (Vegetti, 2003). Consequently, several authors indicate the basic inflorescence in Cyperaceae as a "paniculodium", and similarly the anthelate form as an "anthelodium" (e.g. Kukkonen, 1994; Vegetti, 2003). Variation in the different components of lateral axes in the paniculate pattern results in the known variety of inflorescence forms within Cyperoideae (Raynal, 1971; Goetghebeur, 1986; Vegetti, 2003). Within the inflorescence, branches are usually subtended by primary or involucral bracts (Goetghebeur, 1986). In several genera, higher order branches are 
Fig. 5 LM image of cross section of a spikelet in Hellmuthia membranacea, SEM images of developmental stages in Pycreus pumilus and Lepidosperma tetraquetrum, and theoretical outline of the "Bauplan" of a spikelet in Schoeneae. a LM image of a cross section in the proximal part of a spikelet in Hellmuthia membranacea, with a lateral axis (arrowed). b Lateral view of a spikelet of Pycreus pumilus, with a series of flowers with different numbers of stamens (numbered). c Theoretical diagram of the structure of the distal part of a typical indeterminate cyperoid spikelet. d Interpretive diagram of the structure of the distal part of an indeterminate cyperoid spikelet with hypothesised concaulescent growth of the floral primordium and the internodium. e Lateral view of the distal part of a spikelet in Lepidosperma tetraquetrum. The flowers are tetramerous. There is a large distance between the flower and its subtending glume. The development of the flower is delayed compared with the glume. Captions for Fig. 5. * rachilla apex. $B$ glume-like bract. $F$ flower (primordium). $G$ (flower subtending) glume (primordium). $o v$ ovary. $p$ perianth part. $s$ stamen. $s g$ stigma primordium

subtended by the prophyll of the relative main axis (Meert and Goetghebeur, 1979; Goetghebeur, 1986).

In all genera studied (Table 1), the spikelet consists of an indeterminate rachilla, and spirally to distichously arranged glumes, each subtending (or not) a bisexual (or unisexual) flower (Figs. 4a-i; 5c) (e.g. Eiten, 1976; Kukkonen, 1994; Goetghebeur, 1998). A new glume appears as a rim-like structure, which soon subtends a floral primordium (Fig. 1c). In spikelets with many flowers, the flowers develop acropetally (Figs. 1a; 4a-i). Eiten (1976) defined spikelets as the ultimate branches of the inflorescence axes in Cyperaceae. The terminal spikelet of the main axis is the main florescence, and spikelets terminating lateral branches coflorescences (Vegetti, 2003). A terminal spikelet apparently does not have a subtending bract, nor a prophyll. However, they can be considered to be at the base of the axis (Haines, 1967). By contrast, a lateral spikelet is subtended by a bract (Goetghebeur, 1998), and in most genera it has a prophyll. This spikelet prophyll or proximal glume is always positioned between the rachilla and the relative main axis (Kukkonen, 1994); it is often two-keeled, and always empty (except for the Dulichieae and Cariceae). Weberling (1992) considered a cyperoid spikelet to have the construction pattern of a typical spike. However, this appears to be a simplified view, since in some "spikelets" there are proximal "glumes" subtending a lateral axis, for example in Ficinia (Muasya, unpublished results), Eleocharis (for which Goetghebeur, 1998, termed the proximal glume subtending a vegetative bud "associated bract"), and Hellmuthia (Fig. 5a). According to Timonen (1998), the spikelet concept cannot be maintained in Cariceae. Female flowers occur only in single-flowered "spikelets" axillated by a bract (Fig. 6f). A single-flowered female "spikelet" is considered to be a reduced lateral spike, derived from a compound bisexual branch (Timonen, 1993). A female flower consists only of a gynoecium, which is subtended by a modified prophyll termed the utriculus or perigynium (Timonen, 1998) enveloping the pistillate flower, and often a rudimentary spikelet rachilla (Fig. 4f, Fig. 6d,e). Timonen (1998) considered that a male flower consists of only three stamens subtended by a glume-like bract, which actually subtends an extremely reduced lateral axis. As a result, in Cariceae, a male, female, or bisexual "spikelet" is always homologous with a compound partial inflorescence. Moreover, Timonen (1998) also reported bisexual flowers in other Caricoideae, such as Kobresia and Schoenoxiphium, and the presence of perianth parts in pistillate flowers of Kobresia, suggesting that caricoid flowers originally were closer to the scirpoid pattern. Our preliminary floral ontogenetic results of a rachis apex in Uncinia rubra (Fig. 4e) and 

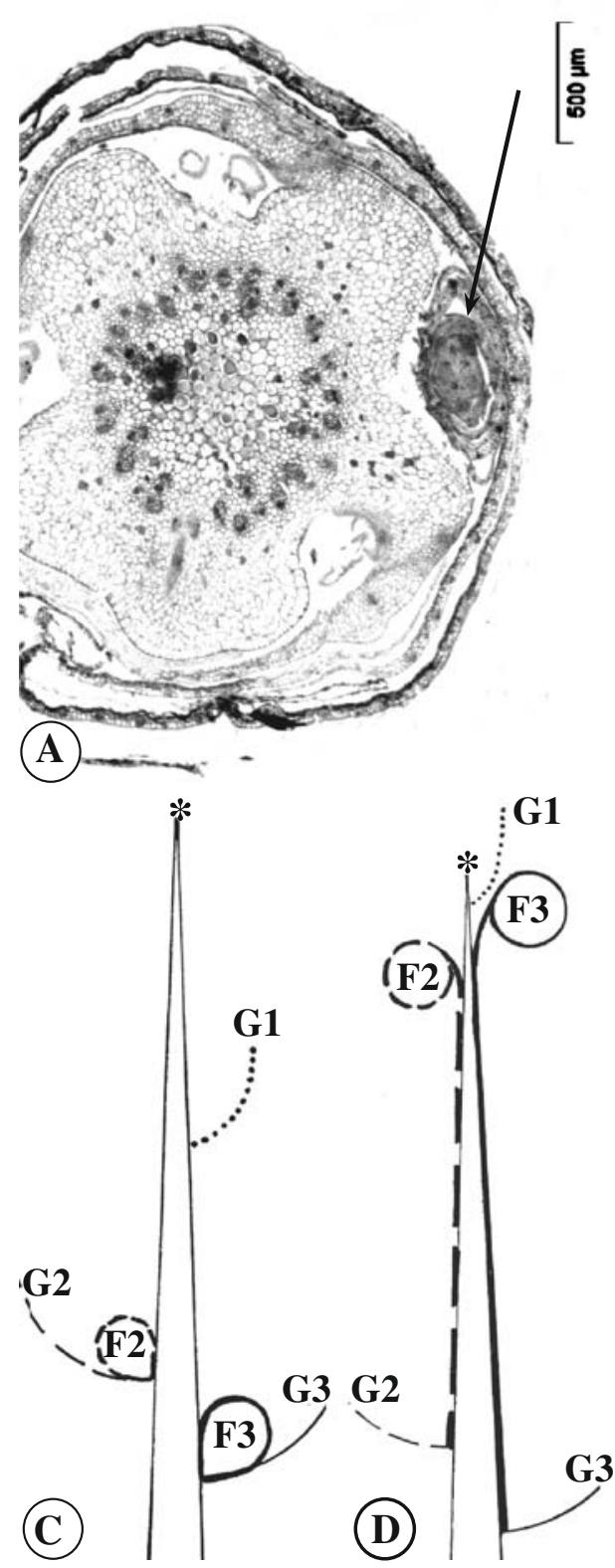
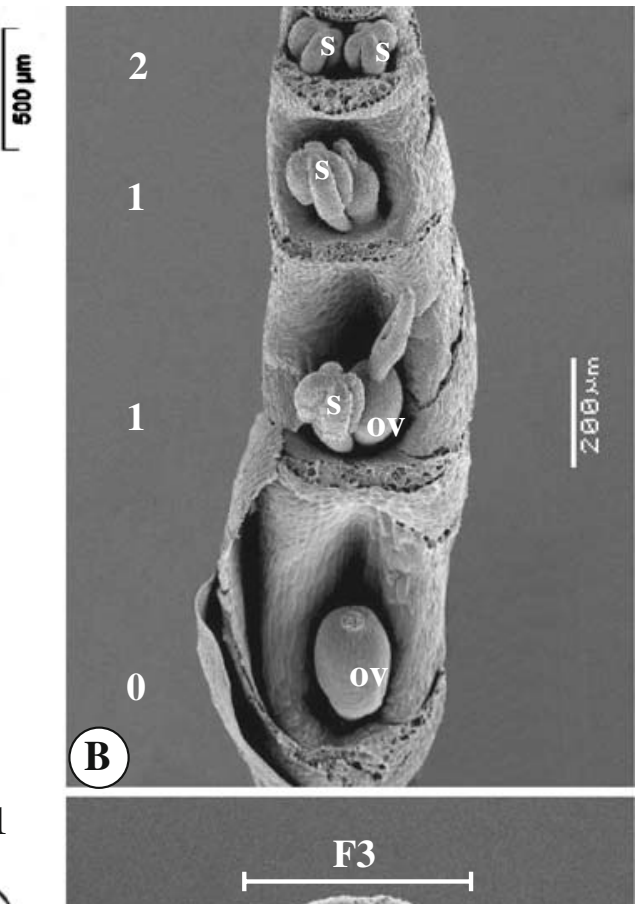

of a developing rachis with male flowers (Fig. 6c), show the typical ontogenetic pattern as observed in scirpoid spikelets and thus far we have not found any (ontogenetic) remnants of a rachilla associated with male "flowers". Therefore, floral ontogenetic investigations in basal genera in Caricoideae are needed to find out whether or not a male "flower" should be considered to be homologous with a bisexual flower, or is subtended by a real glume (or, as Timonen suggested, a glumelike bract). In Schoeneae, we have thus far observed metatopic displacement (Weberling, 1992) of flowers in Schoenus nigricans L. and in Lepidosperma 

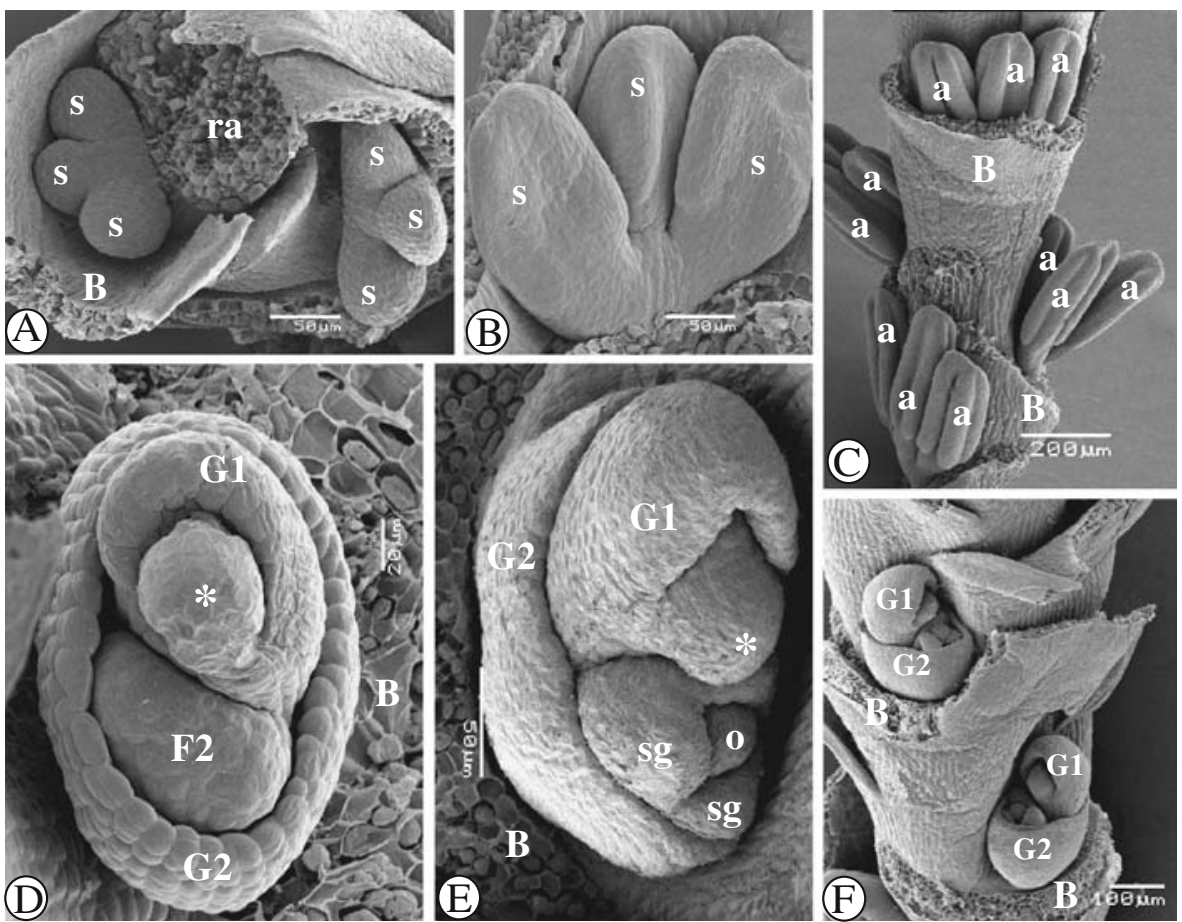

Fig. 6 Floral ontogenetic stages in Uncinia rubra. a Apical view of two male "flowers" on the rachis. b Adaxial view of a developing male "flower". c Central part of the rachis with semi-mature male flowers. d Apical view of an entire female spikelet with a flower primordium $(F 2)$ subtended by the prophyll $(G 2=$ utriculus), and the distal glume $(G l)$ or "hook". The spikelet is subtended by a bract $(B)$. e Apical-lateral view of a female spikelet with developing flower $(G 2=$ prophyll=utriculus). $\mathbf{f}$ Part of the rachis with two developing female spikelets $\left(G 2=\right.$ prophyll=utriculus). Captions for Fig. 6. ${ }^{*}$ rachilla apex. $a$ anther. $B$ (glume-like) bract. $F$ floral primordium. $G$ glume. $o$ ovule primordium. $r a$ rachis. $s$ stamen. $s g$ stigma primordium

tetraquetrum Nees (Fig. 5d,e). A flower in the spikelet is lifted by concaulescent growth with the internode, thereby detached in position from its subtending glume and apparently positioned above the next glume (Vrijdaghs et al., 2007). This phenomenon has also been explained by recaulescence, so that the "spikelet" is seen as a sympodial inflorescence unit resembling a rhipidium (e.g. Celakovsky, 1887; Kükenthal, 1941; Mora, 1960; Kern, 1962; Richards, 2002; Zhang et al., 2004).

The Flower-subtending Glume and the First Floral Ontogenetic Stages

A new glume originates spirally to distichously, immediately under the spikelet apex, as a rim-like structure (Fig. 1b,c). In many species, the glume tends to form lateral wings. This is very common in species with distichously organised spikelets (e.g. the Cypereae). The lateral wings of a glume envelop the rachilla and sometimes even the lower flower, as for example in Schoenus nigricans (Goetghebeur, 1998; Vrijdaghs et al., 2005c). In species with spirally organised spikelets, glumes with wings are less common. In Eleocharis palustris, however, very wide glumes are formed, off of which the lateral sides tend to partially tear in later developmental 


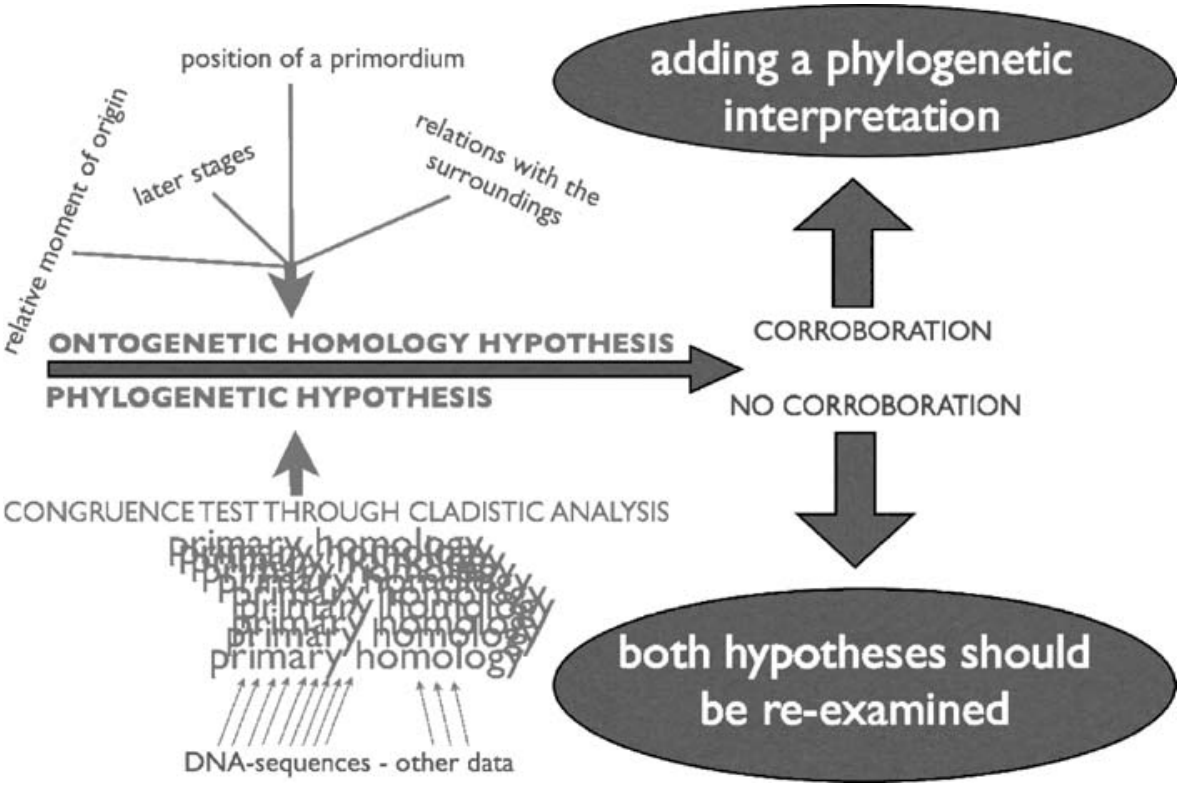

Fig. 7 Theoretical outline of the floral ontogenetic method to formulate a homology hypothesis

stages (Fig. 3b). Similar observations were made in other genera such as Hellmuthia (Vrijdaghs et al., 2006) and Fimbristylis (e.g. Bruhl, 1995).

In the axil of a newly formed glume, a spherical to ellipsoid floral primordium soon appears and expands laterally, forming two lateral staminal primordia. The abaxial stamen primordium appears simultaneously or slightly later (Fig. 1e). Our observations in all genera studied (Table 2) confirm the observations of Payer (1857) and Schumann (1890) that the primordia of the stamens are formed before the first (outer) perianth parts originate. By contrast, Barnard (1957), Sattler (1973), and Mora-Osejo (1987) observed the appearance of the outer perianth parts before any other floral structure.

The floral ontogenetic SEM results in Exocarya (Mapanioideae, Chrysitricheae) of Richards et al. (2006, figures 14-21) show a pattern which differs from the one we have observed in Cyperoideae. The "floral bud" forms first two lateral scale primordia (called "leaf-like structures by Richards et al.) and only then do the stamen primordia appear in a cyperoid-like sequence; after the formation of the three stamen primordia, an adaxial and abaxial scale primordium originates. We obtained similar results in Paramapania (unpublished results), where the differentiation of floral parts on the floral apex with respect to the two lateral scales is even more delayed. By contrast, in Hellmuthia membranacea the two lateral scales, which caused Haines and Lye (1976) to place Hellmuthia within the Mapanioids, originate after the formation of the stamen primordia (Vrijdaghs et al., 2006).

Perianth

A basic cyperoid perianth consists of two alternating whorls with three perianth parts each. In a cyperoid flower, the three stamens are positioned opposite the outer whorl 
of perianth parts (Bruhl, 1991). In all Cyperoid species studied, the perianth appears only after the formation of the stamen primordia. In many species, the perianth parts are reduced to bristles or setae with retrorse prickle hairs. They are deciduous with the fruit, which is probably an adaptation to dispersal by animals (Haines and Lye, 1983). Other forms also occur, such as anchor-shaped scales in Fuirena (Haines and Lye, 1983; Muasya, 1998; Vrijdaghs et al., 2005a), or the smooth ribbon-like perianth parts in Eriophorum (e.g. Mora-Osejo, 1987; Vrijdaghs et al., 2005a).

Influenced by the pseudanthial interpretation of Mattfeld (1938), many authors considered perianth parts to be bracts subtending each a monandrous "flower" (=stamen) (e.g. Kern, 1962; Kukkonen, 1984). Based on Meeuse's (1975) anthocorm hypothesis, a perianth part was also called "glumella" (Meert and Goetghebeur, 1979; Goetghebeur, 1986). To avoid any interpretation or suggestion of a particular morphology, we use the term perianth part for all perianth members that are not bristle-like. In most species studied the perianth parts develop rather slowly in the first stages of floral development (Vrijdaghs et al., 2005a), and then grow rapidly before anthesis. In some species perianth primordia remain underdeveloped (Vrijdaghs et al., 2004, 2005a, b). Consequently, these species are described as "perianth lacking", though floral ontogenetic examination reveals rudimentary perianth primordia. Very often, such primordia do not develop further and are resorbed by postgenital fusion with other tissues during the growth of the plant, so that at mature stages they have become invisible. This was observed in Fuirena pubescens (Vrijdaghs et al., 2004) and Schoenus nigricans (Vrijdaghs et al., 2003a). In Eriophorum, the many ribbon-shaped perianth parts develop from a massive perigonial primordium. Blaser (1941) described them as organised in five fascicles corresponding with five perianth segments, an observation that we cannot confirm (Vrijdaghs et al., 2005a). We concur with Mora-Osejo (1987) that the massive perigonial primordium results from congenital fusion of individual "perigonial" primordia, from which the individual perianth "hairs" originate centripetally in consecutive whorls (Vrijdaghs et al., 2005a). A flower of Dulichium arundinaceum has eight bristles, of which five veins were interpreted as residual traces from the reduction of two unisexual flower-subtending bracts (Mattfeld, 1938), or as the result of splitting of petals along the veins (Blaser, 1941). However, our studies show that the floral ontogenetic pattern in Dulichium arundinaceum is the same as in Scirpus sylvaticus (Mora-Osejo, 1987; Vrijdaghs et al., 2005a).

\section{Androecium}

In a cyperoid flower, there are two lateral-adaxial stamens, and an abaxial one. At maturity, a cyperaceous stamen consists of a stretched filament and a basifixed, introrse anther with two thecae, each with a longitudinal stomium between the two pollen sacs. In many species, the connective between the two thecae forms an apiculus or connective crest (Haines \& Lye, 1983) (Fig. 3g). Many monocots have stomata on the anthers (Lersten, 2004). However, in all species studied by us, no stomata have been observed on the anthers. The lateral staminal primordia are either the first to appear on the floral primordium, or they originate simultaneously with the abaxial stamen primordium. In some species, the abaxial stamen originates with some delay, or does not appear at all (Vrijdaghs et al., 2004, 2005a). Cronquist 
(1981: 1139) reported "stamens most often three, sometimes only two or one, rarely six", but in the species studied by us, the number of stamens varies from zero (in pistillate flowers in Cariceae) to three (most species). In individual plants of some species, the number of stamens varies even among flowers of a single spikelet (e.g. Pycreus pumilus, Fig. 5b). In Schoeneae, however, several species with more than six stamens occur (e.g. Bruhl, 1995; Goetghebeur, 1998).

The stamens remain relatively small until anthesis, then elongate very rapidly, lifting the anthers above the subtending glume (Fig. 3f). Rapid elongation at maturity has been reported in several monocots (e.g. Gould \& Lord, 1988), due rather to cell stretching than cell division (Lersten, 2004).

\section{Gynoecium}

Flowers in Cyperoideae usually have a trimerous superior pistil consisting of a trigonous, unilocular ovary, a long single style and three stigmatic branches. From the earliest developmental stages, no individual carpels can be distinguished. The ovary contains a single, basal, anatropous ovule (Goetghebeur, 1998). Consequently, it is considered to be a derived syncarpous ovary as described by Lersten (2004). Dorsiventrally (e.g. Eleocharis) or laterally flattened pistils (e.g. Pycreus) with two stigmatic branches also occur (Figs. $2 \mathrm{a}-\mathrm{d}, \mathrm{g} ; 5 \mathrm{~b}$ ). The pistil originates from the floral apex, which swells and becomes dome-shaped during the early flower development (Fig. 1f,g). At the floral apex, an annular ovary primordium surrounding a central ovule primordium originates (Fig. 1h-j). Payer (1857: 698) mentioned: “...on voit poindre deux ou trois autres bourrelets... qui sont les rudiments du pistil. D'abord distincts, ils sont promptement réunis à leur base... (one observes two or three other bulges... which are the rudiments of the pistil. First distinct, they become soon fused at their bases...)". However, individual carpel primordia were not observed by Vrijdaghs et al. $(2005 \mathrm{a}, \mathrm{b})$ in any of the species studied. The ovary wall and single style are formed from the annular primordium. In Eleocharis palustris, the thickened, bipartite, persistent style base (Fig. 3c-e) is covered with unicellular trichomes (Fig. 3i) at maturity. The persistent style base might play a role in the dispersion of the fruit, though little seems to be known about this. On the top of the ovary wall usually three (or two in the case of flattened ovaries) stigma primordia appear, two adaxial-lateral and (sometimes with some delay) one abaxial stigma primordium. In a dimerous dorsiventrally flattened pistil the two stigma primordia originate laterally, and in a dimerous laterally flattened pistil they originate dorsiventrally (Fig. 8) (Vrijdaghs et al., 2005a). In some species of Eleocharis, flowers with either two or three stigmatic branches occur in the same plant (Haines \& Lye, 1983). The stigma primordia can be interpreted as the apical parts of a carpel. In Cyperoideae, the ascidiate zone (Leins, 2000) of the three carpels is congenitally fused. In early ontogenetic stages, the congenitally fused plicate zones form the annular ovary primordium. Each stigma primordium is then to be considered homologous with the apical part of the plicate zone (Leins, 2000) of a carpel. The stigma primordia grow out into long papillose stigmatic branches, which at maturity extend above the flower-subtending glume. The Cariceae are characterised by unisexual flowers. A female flower consists only of a pistil. Kukkonen (1967, p. 94) observed in Uncinia "three distinct meristematic swellings at the base of the 


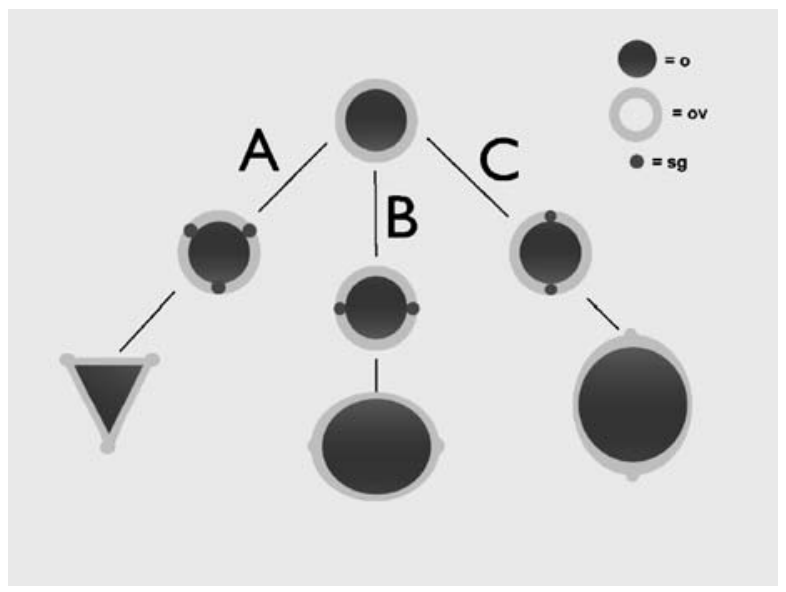

Fig. 8 Diagramatic representation of ontogenetic series of gynoecium development in Cyperoideae. a Ontogenetic series of the development of a trimerous, trigonous gynoecium. b Ontogenetic series of the development of a dimerous, dorsiventrally flattened gynoecium. c Ontogenetic series of the development of a dimerous, laterally flattened gynoecium. Captions for Fig. 8. ov ovary wall. o central ovule. $s g$ stigma primordium

gynoecium" interpreted as "vestigial organs of the female flower... which may represent either stamens or perigonial bristles..., or the hypogynium of a Scleria flower" (Kukkonen, 1967, p. 96), and real stamens were found within the utriculus (Smith \& Faulkner, 1976). According to our preliminary floral ontogenetic results in Cariceae, the gynoecial ontogeny of a female Carex-like flower follows the general pattern observed in other Cyperoideae (Figs. 4f; 6d,e). In Uncinia, the male "flowers" are situated along the distal part of the spike. Its apex, with the earliest ontogenetic stages of the male "flowers", resembles the distal part of an ordinary spikelet (Fig. 6a,b).

In several genera of the Cypereae, there is a tendency to form a hypogynous stalk. In Ficinia, the hypogynous stalk forms lobes enveloping the base of the gynoecium/ nutlet (cupule) (Vrijdaghs et al., 2005b). The hypogynous stalk together with the cupule was called "gynophore" by Haines and Lye (1983). The gynophore lobes were considered by Schönland (1922) to be homologous with the inner whorl of stamens, which is not confirmed by our observations.

\section{Conclusions}

The spikelet and floral ontogeny of all species studied occurs according to a general, Scirpus-like pattern. Spikelets consist of an indeterminate rachilla, on which new glumes originate spirally to distichously. Each glume subtends (or not) a bisexual flower (except in Cariceae and Sclerieae). On the floral primordium, two lateral stamen primordia appear, before or simultaneously with the abaxial one. At the same time, a gynoecium primordium originates at the floral apex, which subsequently differentiates into an annular ovary primordium surrounding a central ovule 
primordium. If present, perianth parts $(3-\infty)$, appear after the formation of the stamen primordia, and simultaneously with the appearance of the annular ovary primordium. In species in Cyperoideae with more than six perianth members, the floral ontogeny follows a general, scirpoid pattern. The annular ovary primordium grows up to form the ovary wall and a single style. On the top of the ovary wall three (or two) stigma primordia appear, which grow out into long papillose stigmatic branches. In many genera, there is a tendency to form a hypogynous stalk. In Ficinia, a cupule grows out from the hypogynous stalk, which is persistent on the fruit. Variations upon the general floral ontogenetic pattern for Cyperoideae occur in the number of stamens, the number and morphology of the perianth parts, and the number and position of the stigma primordia. In Schoeneae, metatopic displacement of the flowers by concaulescent growth with the internode occurs, combined with a floral ontogenetic delay compared with the development of the subtending glume. By applying the general floral ontogenetic model for Cyperoideae, the nature of the bristles in Dulichium, the perianth hairs in Eriophorum, the inner perianth parts in Fuirena, and the lateral scales in Hellmuthia has been clarified, as well as the structure of the spikelet in the controversial species Schoenus nigricans.

\section{Forthcoming Research}

Further floral and spikelet research in the Cariceae is needed in order to establish the nature of the male "flower" and to give more insight in the complex inflorescence structures. Our on-going research includes spikelet developmental studies in Cypereae. We also concentrate on the origin of dimerous gynoecia in genera such as Kyllinga, Pycreus and Queenslandiella, including anatomical and molecular data of Reynders et al. (2005). In Schoeneae, an elaborate spikelet and floral ontogenetic study should clarify the nature of the spikelet, as well as the occurrence of several modifications in the floral structure, such as tetramery. In the long term, the spikelet and floral ontogeny in genera of all former tribes (sensu Goetghebeur, 1998) will be studied. We also intend to include species in the subfamily Mapanioideae, to complement the work of other groups such as Richards et al. (2006).

Acknowledgements We thank the organisers of the symposium "Sedges have edges-phylogenetic relationships and evolution" at the XVII International Botanical Congress in Vienna, Austria 2005. We thank Marcel Verhaegen, for assistance with SEM observations at the National Botanic Garden of Belgium in Meise, Anja Vandeperre (Laboratory of Systematics, K.U. Leuven), for professional help with the LM preparations and drawings, and professor Dr. Hilda Flores (University of Mexico) for translating the abstract in Spanish. This work was supported financially by research grants of the K.U. Leuven (0T/05/35) and the Fund for Scientific Research-Flanders (FWO-Vlaanderen, Belgium, G.0268.04). A.M. Muasya was a visiting postdoctoral fellow of the Fund for Scientific Research-Flanders (FWO-Vlaanderen, Belgium) and of the K.U. Leuven.

\section{Literature Cited}

APG. 2003. An update of the angiosperm phylogeny group classification for the orders and families of flowering plants: APG II. Botanical Journal of the Linnean Society 141: 399-436. 
Barnard, C. 1957. Floral histogenesis in the Monocotyledons. 2. The Cyperaceae. Australian Journal of Botany 5: 115-128.

Blaser, H. W. 1941. Studies in the morphology of the Cyperaceae I. Morphology of flowers. A. Scirpoid genera. American Journal of Botany 28: 542-551.

Bruhl, J. J. 1991. Comparative development of some taxonomically critical floral/inflorescence features in Cyperaceae. Australian Journal of Botany 39: 119-127.

Bruhl, J. J. 1995. Sedge genera of the world: relationships and a new classification of the Cyperaceae. Australian Systematic Botany 8: 125-305.

Celakovsky, L. 1887. Ueber die ährchenachtige Partial-inflorescenzen der Rhynchosporeen. Berichte der Deutschen Botanischen Gesellschaft V.I: 148-152.

Cronquist, A. 1981. An integrated system of classification of flowering plants. Columbia University Press, New York.

Dahlgren, R. M. T., H. T. Clifford, \& P. F. Yeo. 1985. The families of the monocotyledons. Structure, evolution, and taxonomy, 407-414. Springer, Berlin.

Eiten, L. T. 1976. Inflorescence units in the Cyperaceae. Annals of the Missouri Botanical Garden 63: 81-112.

Goetghebeur, P. 1986. Genera Cyperacearum. Een bijdrage tot de kennis van de morfologie, systematiek en fylogenese van de Cyperaceae-genera. PhD thesis, Groep Plantkunde, Rijksuniversiteit Gent. Gent.

- 1998. Cyperaceae. Pages 141-190. In: Kubitzki K. (Ed.), The families and genera of vascular plants IV Flowering plants-Monocotyledons. Springer, Berlin.

Haines, R. W. 1967. Prophylls and branching in Cyperaceae. Journal of the East African Natural History Society XXVI (1): 51-70.

Haines, R. W. \& K. A. Lye. 1976. Studies in African Cyperaceae XIV. The genus Hellmuthia Steud. Botaniska Notiser 129:61-68.

Haines, R. W. \& K. A. Lye. 1983. The sedges and rushes of East Africa. East African National History Society, Nairobi.

Holttum, R. E. 1948. The spikelet in Cyperaceae. Botanical Review 14:525-541.

Gould, K. S. \& E. M. Lord. 1988. Growth of anthers in Lilium longiflorum: a kinematic analysis. Planta 173: $161-171$.

Kern, J. H. 1962. New look at some Cyperaceae mainly from the tropical standpoint. Advancement of Science 19: 141-148.

Kubitzki, K. 1987. Origin and significance of trimerous flowers. Taxon 36(1): 21-28.

Kukkonen, I. 1967. Spikelet morphology and anatomy of Uncinia Pers. (Cyperaceae). Kew Bulletin 21: 93-97.

- 1984. On the inflorescence structure in the family Cyperaceae. Annales Botanici Fennici 21: 257264.

1994. Definition of descriptive terms for the Cyperaceae. Annales Botanici Fennici 31: 37-43.

Kükenthal, G. 1941. Vorarbeiten zu einer monographie der Rhynchosporoideae. X. Feddes Repertorium Specierum Novarum Regni Vegetabilis 50(1-5): 19-50.

Lauder, G. V. 1994. Homology, form, and function. In: B. K. Hall (Ed.) Homology: the hierarchical basis of comparative biology. Academic, San Diego.

Leins, P. 2000. Blüte und Frucht. Morphologie, Entwicklungsgeschichte, Phylogenie, Funktion, Ökologie. E. Schweizerbart'sche Verlagsbuchhandlung (Nägele u. Obermiller). Stuttgart, Germany.

Lersten, N. R. 2004. Flowering plant embryology. Blackwell, IA.

Mattfeld, J. 1938. Das morphologische Wesen und die phylogenetische Bedeutung der Blumenblätter. Berichte der Deutschen Botanischen Gesellschaft 56: 86-116.

Meert, M. \& P. Goetghebeur. 1979. Comparative floral morphology of Bisboeckelereae and Cariceae (Cyperaceae) on the basis of the anthoid concept. Bulletin van de Koninklijke Belgische Botanische Vereniging/Bulletin de la Société Royale de Botanique Belge 112: 128-143.

Meeuse, A. D. J. 1975. Interpretative floral morphology of the Cyperaceae on the basis of the anthoid concept. Acta Botanica Neerlandica 24: 23-36.

Mora, L. E. 1960. Beitrage zur Entwicklungsgeschichte und vergleichende Morphologie der Cyperaceen. Beiträge zur Biologie der Pflanzen 35: 253-341.

Mora-Osejo, L. E. 1987. Consideraciones sobre la naturaleza morfologica de las flores de algunes generos de las Cyperaceae. Revista de la Academia Colombiana de Ciencias Exactas, Físicas y Naturales 16: 23-35.

Muasya, A. M. 1998. A synopsis of Fuirena (Cyperaceae) for the flora of tropical East Africa. Kew Bulletin 53: 187-202. 
D. A. Simpson, A. Culham \& M. W. Chase. 1998. An assessment of suprageneric phylogeny in Cyperaceae using rbcL DNA sequences. Plant Systematics and Evolution 211: 257-271.

$\longrightarrow,-$ G. A. Verboom, P. Goetghebeur, R. F. C. Naczi, M. W. Chase \& E. Smets. Phylogeny of Cyperaceae based on DNA sequence data: current progress and future prospects. Botanical Review (this volume)

- J. J. Bruhl, D. A. Simpson, A. Culham \& M. W. Chase. 2000. Suprageneric phylogeny of Cyperaceae: a combined analysis. In K.L. Wilson and D.A. Morrison (Eds.), Monocots: systematics and evolution, 593-601. CSIRO, Melbourne.

—, A. Vrijdaghs, D. A. Simpson, M. W. Chase, P. Goetghebeur \& E. Smets. What is a genus in Cypereae: phylogeny, character homology assessment and generic circumscription. Botanical Review (this volume B)

Nelson, G. 1994. Homology and systematics. In: Homology: the hierarchical basis of comparative biology. Ed. B. K. Hall, Academic press, Inc. San Diego, California.

Pax, F. 1886. Beitrage zur Morphologie und Systematik der Cyperaceen. Botanische Jahrbüche VII: 287318.

Patterson, C. 1982. Morphological characters and homology. In: K. A. Joysey \& A. E. Friday (Eds.) Problems of phylogenetic reconstruction. Academic, London.

Payer, J. B. 1857. Traité d'organogénie comparée de la fleur. Masson: Paris.

Plunkett, G. M., D. E. Soltis, P. S. Soltis \& R. E. Brooks. 1995. Phylogenetic relationships between Juncaceae and Cyperaceae based on $r b c L$ sequence data. American Journal of Botany 82: 520-525.

Raynal, J. 1971. Quelques notes morphologiques sur les Cypéracées. Mitteilungen der Botanische Staatssammlung München 10: 589-603.

Remane, A. 1952. Die Grundlage des natürlichen Systems, der vergleichende Anatomie und der Phylogenetik. Akademische Verlagsgelellschaft, Leipzig.

Reynders, M., P. Goetghebeur \& L. Majesky. 2005. Nutlet anatomy, a key character in the taxonomy of Pycreus (Cyperaceae). Doctoraatssymposium faculteit Wetenschappen, U. Gent. Book of abstracts: p. 113.

Richards, J. 2002. Flower and spikelet morphology in sawgrass, Cladium jamaicense Crantz (Cyperaceae). Annals of Botany 90: 361-367.

— J. J. Bruhl \& K. L. Wilson. 2006. Flower or spikelet? Understanding the morphology and development of reproductive structures in Exocarya (Cyperaceae, Mapanioideae, Chrysitricheae). American Journal of Botany 93(9): 1241-1250.

Rudall, P. J. \& R. M. Bateman. 2003. Evolution of zygomorphy in monocot flowers: iterative patterns and developmental constraints. New Phytologist 162: 25-44.

Sattler, R. 1973. Organogenesis of flowers. A photographic text-atlas. University of Toronto Press, Toronto. 207 pp. 1984. Homology - a continuing challenge. Systematic Botany 9(4): 382-394.

1994. Homology, homeosis, and process morphology in plants. In: B.K. Hall (Ed.) Homology: the hierarchical basis of comparative biology. Academic, San Diego

Smith, D. L. \& J. S. Faulkner. 1976. The inflorescence of Carex and related genera. Botanical Review 42: 53-81.

Schultze-Motel, W. 1959. Entwicklungsgeschichtliche und vergleichend-morphologische Untersuchungen im Blütenbereich der Cyperaceae. Bot. Jahrb. Syst. 78: 129-170.

Schumann, X. 1890. Neue Untersuchungen über den Blüthenanschluss. Verlag von Wilhelm Engelmann, Leipzig pp. 37-55.

Schönland, S. 1922. South African Cyperaceae. Memoirs of the Botanical Survey of South Africa 3, Pretoria, S. Africa.

Simpson, D. 1995. Relationships within Cyperales. In: Rudall P. J., Cribb P. J., Cutler D. F., Humphries C. J. (Editors). Monocotyledons: systematics and evolution. Royal Botanic Gardens Kew, UK. pp. 497509 .

Simpson, D. A., A. M. Muasya, M. Alves, J. J. Bruhl, S. Dhooge, M. W. Chase, C. A. Furness, K. Ghamkhar, P. Goetghebeur, T. R. Hodkinson, A. D. Marchant, R. Nieuborg, A. A. Reznicek, E. H. Roalson, E. Smets, J. R. Starr, W. W. Thomas, K. L. Wilson \& X. Zhang. 2007. Phylogeny of Cyperaceae based on DNA sequence data - a new rbcL analysis. In: MonocotsIII/Grasses IV. Claremont, CA: Aliso 23: 00-00, Rancho Santa Ana Botanic Garden.

Timonen, T. 1993. Synflorescence structure of some hetero-, homo-, and monostachyae sedges (Carex, Cyperaceae). Annales Botanici Fennici 30: 21-42.

- 1998. Inflorescence structure in the sedge tribe Cariceae (Cyperaceae). Publications in Botany from the University of Helsinki 26: 1-35. 
Troll, W. 1959. Allgemeine Botanik. Ein Lehrbuch auf vergleidend-biologischer Grundlage. Ferdinand Enke Verlag Stuttgart, Germany.

Vegetti, A. C. 2003. Synflorescence typology in Cyperaceae. Annales Botanici Fennici 40: 35-46

Vrijdaghs, A., P. Goetghebeur, E. Smets \& P. Caris. 2003a. The Schoenus L. spikelet a rhipidium? A floral ontogenetic approach. In: Bayer, C., Dressler, S., Schneider, J. \& G. Zizka (eds.) 16th International Symposium Biodiversity and Evolutionary Biology, 17th International Senckenberg Conference. Abstracts: 24. Palmarum Hortus Francofurtensis 7, Frankfurt am Main.

, P. Goetghebeur, E. Smets \& P. Caris. 2003b. The orientation of the developing gynoecium of Cladium mariscus (L.) Pohl. In: Bayer, C., Dressler, S., Schneider, J. \& G. Zizka (eds.) 16th International Symposium Biodiversity and Evolutionary Biology, 17th International Senckenberg Conference. Abstracts: 24. Palmarum Hortus Francofurtensis 7, Frankfurt am Main.

, P. Goetghebeur, A. M. Muasya, E. Smets \& P. Caris. 2004. The nature of the perianth in Fuirena (Cyperaceae). South African Journal of Botany 70(4): 587-559.

, P. Caris, P. Goetghebeur \& E. Smets. 2005a. Floral Ontogeny in Scirpus, Eriophorum, and Dulichium (Cyperaceae), with special reference to the perianth. Annals of Botany 95: 1199-1209.

, P. Goetghebeur, A. M. Muasya, P. Caris \& E. Smets. 2005b. Floral ontogeny in Ficinia Schrad. and Isolepis R.Br. (Cyperaceae), with focus on the nature and origin of the gynophore. Annals of Botany 96: 1247-1264.

P. Goetghebeur, E. Smets \& A. M. Muasya. 2006. The lateral floral scales in Hellmuthia (Cyperaceae, Cyperoideae) and Paramapania (Cyperaceae, Mapanioideae), a floral ontogenetic study. Annals of Botany 98: 619-630.

—, P. Goetghebeur, E. Smets \& P. Caris. 2007. The Schoenus spikelet: a rhipidium? A floral ontogenetic answer. In J. T. Columbus, E. A. Friar, J. M. Porter, L. M. Prince, and M. G. Simpson [eds.], Monocots: comparative biology and evolution-Poales. Aliso 23: 00-00. Rancho Santa Ana Botanic Garden, Claremont.

Weberling, F. 1992. Morphology of flowers. Cambridge University Press, Cambridge.

Zhang, X., K. L. Wilson \& J. J. Bruhl. 2004. Sympodial structure of spikelets in the tribe Schoeneae (Cyperaceae). American Journal of Botany 91: 24-36. 